\title{
CO-DIGESTION OF MOLASSES WITH DRY GRAIN SWEEPS AND BIRCH LEAVES
}

\author{
Vilis Dubrovskis, Imants Plume, Indulis Straume \\ Latvia University of Life Sciences and Technologies, Latvia \\ vilisd@inbox.lv,imants.plume@1lu.1v, indulis.straume@1lu.lv
}

\begin{abstract}
Support for biogas production in Latvia has decreased. There is an urgent need to investigate the suitability of various inexpensive renewable biomass resources for energy production. Also, it is necessary to explore the possibilities to improve the anaerobic digestion process with the help of various catalysts. Molasses is a good raw material for co-digestion with biomass having low biodegradability. The article shows the results of studies on biogas (methane) production from dry grain sweeps, birch leaves and from their co-digestion with molasses. The anaerobic digestion process was performed in 0.751 laboratory digesters, operated in batch mode $(38 \pm 1.0,32$ days). The average specific biogas or methane production per unit of dry organic matter added (DOM) from molasses was $0.840 \mathrm{l} \cdot \mathrm{g}^{-1}$ DOM or $0.457 \mathrm{l} \cdot \mathrm{g}^{-1}$ DOM respectively. Average specific biogas or methane volume produced from dry grain sweeps (residues) in anaerobic fermentation was $0.777 \mathrm{l} \cdot \mathrm{g}^{-1}$ DOM or $0.402 \mathrm{l} \cdot \mathrm{g}^{-1}$ DOM respectively. Average biogas or methane yield from co-digestion of dry grain sweeps and molasses was $0.772 \mathrm{l} \cdot \mathrm{g}^{-1}$ DOM or $0.433 \mathrm{l} \cdot \mathrm{g}^{-1}$ DOM respectively. Average specific biogas or methane yield from anaerobic fermentation of birch leaves and molasses was $0.737 \mathrm{l} \cdot \mathrm{g}^{-1}$ DOM or $0.369 \mathrm{l} \cdot \mathrm{g}^{-1}$ DOM respectively. All investigated biomass resources can be used for methane production.
\end{abstract}

Key words: anaerobic digestion, biogas, methane, dry grain sweeps, molasses, birch leaves.

\section{Introduction}

The need to develop and improve the technologies and methods for sustainable bioenergy resources usage is considerable due to the finite nature of our fossil fuels."Bioenergy can be generated from organic waste materials, which might otherwise be discarded, thus contributing to the waste management. Usage of waste biomass for biogas production can minimise the competition between energy crop and edible crop production" [1]. Such waste biomass are grain processing residues produced in amount up to $15 \%$ of processed grain biomass in grain processing plants in Latvia. These grain processing wastes (bran, chaff and sweepings) are usable, in dependence on the residue quality, for animal feed or for energy production. There are many birch, oak and other tree leaves falling in the autumn and after collecting the leaves are transported to landfills.

Both grain sweeps and tree leavescontain lot oflignin having low biodegradability in the anaerobic digestion (AD) process. Bacteria and enzymes, and other additives can facilitate the anaerobic digestion $(\mathrm{AD})$ process of lignin rich biomass.

Our previous studies showed the beneficial effect of sugar-rich biomass (damaged jam, sweets factory wastewater, molasses, etc.) on the anaerobic fermentation process resulting in increase of the biogas yield [2;3]. This is also evidenced by publications of other researchers. "Two-stage anaerobic digestion process has been frequently applied to the sequential production of hydrogen and methane from various organic wastes. In this study, a cost-effective by-product of food industry, molasses, was used as a sole carbon source for the two-stage biogas-producing process. The two-stage process consisted of two reactors, the first-stage operated at $\mathrm{pH} 5.5$ and $35^{\circ} \mathrm{C}$ and the second-stage methanogenic reactor at $\mathrm{pH} 7.0$ and $35^{\circ} \mathrm{C}$. Microbial community analysis revealed that Clostridium butyricum was the major hydrogen-producing bacteria and methanogens consisted of hydrotrophic bacteria like Methanobacterium beijingense and acetotrophic bacteria like Methanothrix soehngenii. In the first-stage process, hydrogen could be efficiently produced from diluted molasses with the highest production rate of $2.8( \pm 0.22) \mathrm{L}-\mathrm{H} 2 / \mathrm{L}-$ reactor/d at the optimum HRT of $6 \mathrm{~h}$. In the second-stage process, methane could be also produced from residual sugars and VFAs with a production rate of $1.48( \pm 0.09) \mathrm{L}-\mathrm{CH} 4 / \mathrm{L}-$ reactor/d at the optimum HRT of $6 \mathrm{~d}$, at which overall COD removal efficiency of the two-stage process was determined to be $79.8 \%$. Finally, economic assessment supported that cost-effective molasses was a potent carbon source for the sequential production of hydrogen and methane by the two-stage anaerobic digestion process" [4].

Another publication by the same researchers deals with $\mathrm{AD}$ processing of concentrated molasses. "Concentrated molasses (C5 molasses) from the 2nd generation bioethanol plant has been investigated for enhancing productivity of manure as raw material-based digesters. A batch study at mesophilic condition $\left(35 \pm 1{ }^{\circ} \mathrm{C}\right)$ showed the maximum methane yield from molasses as $286 \mathrm{~L} \mathrm{CH} 4 \mathrm{~kg}-1 \mathrm{VSwhich}$ 
was approximately $63 \%$ of the calculated theoretical yield. In addition to the batch study, co-digestion of molasses with cattle manure in a semi-continuously stirred reactor at thermophilic temperature $\left(50 \pm 1^{\circ} \mathrm{C}\right)$ was also performed with a stepwise increase in the molasses concentration. The results from this experiment revealed the maximum average biogas yield of $1.89 \mathrm{~L} / \mathrm{L} /$ day, when $23 \% \mathrm{VS}$ molasses was co-digested with cattle manure. However, the digesters fed with more than $32 \%$ VS molasses and with a short adaptation period resulted in VFA accumulation and reduced methane productivity indicating that, when using molasses as biogas booster this, level should not be exceeded" [5].

Fallen leaves biodegrade under aerobic conditions and release not only carbon dioxide, but also some amount of methane. Japanese researchers suggested that forests are major methane sources. It is therefore important to determine the contribution of temperate forests to worldwide methane gas evolution. "We studied methane emission from typical tree species native to northern Japan grown under both ambient and high $\mathrm{CO} 2$ concentrations $(\mathrm{CO} 2)$, and accordingly considered the methane emission rates on the global scale. We used three tree species: larch (Larix kaempferi (Lamb.) Carriere), birch (Betula maximo wicziana Regel) and oak (Quercus mongolica Fisch. Ex Ledeb. var. crispula (Blume) Ohashi). Fresh leaves were incubated at $35^{\circ} \mathrm{C}$ under illumination and methane emission was monitored at $24 \mathrm{hr}$ intervals. Methane emission was observed in the leaves of all three species; specific patterns were found. Larch produced the most methane. Oak produced the least methane at high $\mathrm{CO} 2$ concentration. There are currently large variations in estimates of the total methane emission on the global scale. The present results suggest that further accurate methane flux studies are necessary in order to determine the total methane emission rates from fallen leaves at the global scale" [6].

Scientists from Sweden studied methane exchange by tree leaves and found that live tree leaves can uptake methane from atmosphere, so contributing in reduction of methane in the ambient atmosphere and the greenhouse effect. "At a forest site in central Sweden in situ branch chamber measurements were used to study plant ambient $\mathrm{CH} 4$ exchange by spruce (Picea abies), birch (Betula pubescens), rowan (Sorbus aucuparia) and pine (Pinus sylvestris). The results show a net uptake of $\mathrm{CH} 4$ by all studied plants, which might be of importance for the methane budget. The average $\mathrm{CH} 4$ uptake per unit of leaf area across all species in the environmental conditions for the in-situ measurements was $0.7 \mu \mathrm{mol} \cdot \mathrm{m}^{-2} \cdot \mathrm{h}^{-1}$ " [7].

To stop the methane production from leaves in the autumn, after falling on the ground, it is possible to use leaves for methane production in favourable conditions in digesters, by following burning of methane in engines or burners. For enhancement of the methane yield from leavesdifferent additives and catalysts may be used. Digestate produced after the AD process can be used as organic fertilizer applicable for soils, including forest soils, fertilization.

The aim of this study is to evaluate the biogas and methane production from the molasses, fallen birch leaves and grain residues to justify whether the co-fermentation of molasseswith fallen birch leaves and grain residues can cause any positive effect.

\section{Materials and methods}

Before fermentation the raw material (molasses, birch leaves and grain residues(sweeps) samples were analysed for dry matter and organic matter content. Fallen birch leaves were chopped. Data were used for calculation of organic load rates. The widely applied methods were used for the AD process investigation [8;9] in 16 experimental bioreactors with the volume of 0.75 litres. 2 bioreactors for control were refilled with $500.0 \pm 0.2 \mathrm{~g}$ inoculums and the rest bioreactors were refilled with mixtures of inoculums ( $500 \mathrm{~g}$ ), added biomass $(20 \pm 0.005 \mathrm{~g}$ ), according to the experimental plan, see Table 1 .

The bioreactors R2-R5 were refilled with $20 \mathrm{~g}$ of molasses, the bioreactors R6-R8 were refilled with $20 \mathrm{~g}$ of grain residues sweeps, the bioreactors R9-R12 were refilled with $10 \mathrm{~g}$ of molasses and $10 \mathrm{~g}$ of grain sweeps and the bioreactors R13-R15 were refilled with $10 \mathrm{~g}$ of molasses and $10 \mathrm{~g}$ of birch leaves.

Dry organic matter (DOM) content was determined by weighting of the initial biomass samples, dried in the thermostat at $105^{\circ} \mathrm{C}$ and placed in the oven ("Nabertherm" type) at $550{ }^{\circ} \mathrm{C}$. All the components were carefully mixed together and refilled in bioreactors. All bioreactors were placed into 
the heated thermostat at the same time before starting of anaerobic digestion. Gas released from each bioreactor was collected in a storage bag positioned outside the thermostat. Gas volumes were measured using the flow meter (Ritter drum-type gas meter). The composition of gases, including oxygen, carbon dioxide, methane and hydrogen sulphide, was measured by help of the gas analyser (model GA 2000). The substrate $\mathrm{pH}$ value was measured before and after finishing the AD process, using a pH meter (model PP-50) with accessories. Scales (Kern, model KFB 16KO2) was used for weighting of the total weight of substrates before and after the AD process.

Fermented cattle manure (from 1201 bioreactor working in continuous mode) was used as the inoculum. The batch mode AD process was ongoing at temperature $38 \pm 0.5^{\circ} \mathrm{C}$. Biogas released was collected in gas bags for further measurements of the gas volume and elemental composition. Biogas and methane volumes and gases composition were measured during the $\mathrm{AD}$ process at regular time intervals. The AD process was provided until biogas emission ceased ( 32 days). The obtained experimental data were processed using appropriate statistical methods.

\section{Results and discussion}

The results of the investigation of sample substrates, including inoculums, molasses, birch leaves and grain residues, before starting the $\mathrm{AD}$ process are shown in Table 1.

Results of analyses of raw material samples before anaerobic digestion

\begin{tabular}{|c|c|c|c|c|c|c|c|c|}
\hline $\begin{array}{c}\text { Bio- } \\
\text { reactors }\end{array}$ & Raw material & $\mathbf{p H}$ & $\begin{array}{c}\text { TS, } \\
\mathbf{\%}\end{array}$ & $\begin{array}{c}\text { TS, } \\
\mathbf{g}\end{array}$ & $\begin{array}{c}\text { ASH, } \\
\mathbf{\%}\end{array}$ & $\begin{array}{c}\text { DOM, } \\
\mathbf{\%}\end{array}$ & $\begin{array}{c}\text { DOM, } \\
\mathbf{g}\end{array}$ & $\begin{array}{c}\text { Weight, } \\
\mathbf{g}\end{array}$ \\
\hline R1; R16 & IN & 7.52 & 3.63 & 18.15 & 28.13 & 72.88 & 13.228 & 500 \\
\hline R2-R5 & M & & 86.56 & 17.312 & 26.30 & 73.70 & 12.759 & 20 \\
\hline R6-R8 & GS & & 80.25 & 16.05 & 10.54 & 89.46 & 14.358 & 20 \\
\hline R9- R12 & $500 I N+10 \mathrm{M}+10 G S$ & 7.51 & 6.70 & 34.831 & 23.10 & 76.90 & 26.786 & 520 \\
\hline R13-R15 & 500IN + 10M + 10BL & 7.55 & 6.64 & 34.541 & 22.81 & 77.19 & 26.664 & 520 \\
\hline R2-R5 & 500IN + 20M & 7.58 & 6.82 & 35.462 & 26.72 & 73.28 & 25.987 & 520 \\
\hline R6- R8 & 500IN + 20GS & 7.54 & 6.58 & 34.2 & 19.34 & 80.66 & 27.586 & 520 \\
\hline R13-R15 & 500IN + 10BL & & 77.35 & 7.735 & 8.76 & 91.24 & 7.057 & 10 \\
\hline
\end{tabular}

Note: IN-inoculum; $M$ - molasses; GS-grain residues (sweeps); $B L$ - birch leaves; $A S H$ - ashes; TS - total solids; DOM - dry organic matter (on raw substrate basis); R1-R16 - bioreactors.

As it can be seen from Table 1, all raw materials have a high dry matter and organic dry matter content. These are good raw materials for biogas production. The biogas and methane yields from the bioreactors R2-R15 with added biomass are shown in Table 2 and Fig. 1 with already subtracted average values of biogas and methane obtained from the control reactors R1 and R16 refilled with pure inoculum.

Table 2

Biogas and methane yields

\begin{tabular}{|c|c|c|c|c|c|c|}
\hline Bioreactor & Raw material & $\begin{array}{c}\text { Biogas, } \\
\text { l }\end{array}$ & $\begin{array}{l}\text { Biogas, } \\
l \cdot \mathrm{g}^{-1} \text { DOM }\end{array}$ & $\begin{array}{c}\text { Methane, } \\
\text { aver. \% }\end{array}$ & $\begin{array}{c}\text { Methane, } \\
\text { l }\end{array}$ & $\begin{array}{c}\text { Methane, } \\
l \cdot g^{-1} \text { DOM }\end{array}$ \\
\hline $\mathrm{R} 1$ & $500 I N$ & 0.2 & 0.015 & 2.30 & 0.005 & 0.0004 \\
\hline R16 & $500 \mathrm{IN}$ & 0.2 & 0.015 & 2.40 & 0.005 & 0.0004 \\
\hline \multicolumn{2}{|c|}{ Average R1, R16 } & 0.2 & 0.015 & 2.35 & 0.005 & 0.0004 \\
\hline $\mathrm{R} 2$ & $500 \mathrm{IN}+20 \mathrm{M}$ & 11.3 & 0.886 & 53.99 & 6.101 & 0.478 \\
\hline R3 & $500 \mathrm{IN}+20 \mathrm{M}$ & 11.6 & 0.909 & 55.88 & 6.482 & 0.508 \\
\hline $\mathrm{R} 4$ & $500 \mathrm{IN}+20 \mathrm{M}$ & 10.0 & 0.784 & 53.28 & 5.328 & 0.418 \\
\hline R5 & $500 \mathrm{IN}+20 \mathrm{M}$ & 10.0 & 0.784 & 54.02 & 5.402 & 0.423 \\
\hline \multicolumn{2}{|c|}{ Average R2- R5 } & 10.73 & 0.840 & 54.29 & 5.828 & 0.457 \\
\hline \pm st.dev. & & \pm 0.85 & \pm 0.066 & \pm 1.11 & \pm 0.558 & \pm 0.044 \\
\hline
\end{tabular}


Table 2 (continued)

\begin{tabular}{|c|c|c|c|c|c|c|}
\hline Bioreactor & Raw material & $\begin{array}{c}\text { Biogas, } \\
\text { I }\end{array}$ & $\begin{array}{l}\text { Biogas, } \\
l^{\cdot} \text { g }^{-1} \text { DOM }\end{array}$ & $\begin{array}{l}\text { Methane, } \\
\text { aver. \% }\end{array}$ & $\begin{array}{c}\text { Methane, } \\
\text { I }\end{array}$ & $\begin{array}{c}\text { Methane, } \\
l \cdot g^{-1} \text { DOM }\end{array}$ \\
\hline R6 & $500 \mathrm{IN}+20 \mathrm{GS}$ & 11.5 & 0.801 & 49.90 & 5.738 & 0.399 \\
\hline $\mathrm{R} 7$ & $500 \mathrm{IN}+20 \mathrm{GS}$ & 11.7 & 0.815 & 52.10 & 6.096 & 0.425 \\
\hline $\mathrm{R} 8$ & $500 \mathrm{IN}+20 \mathrm{GS}$ & 10.3 & 0.717 & 53.20 & 5.480 & 0.382 \\
\hline \multicolumn{2}{|c|}{ Average:R6-R8 } & $\begin{array}{l}11.17 \\
+076\end{array}$ & $\begin{array}{c}0.777 \\
+0.053\end{array}$ & $\begin{array}{r}51.73 \\
+1.68\end{array}$ & $\begin{array}{c}5.771 \\
+0309\end{array}$ & $\begin{array}{c}0.402 \\
+0.022\end{array}$ \\
\hline R9 & $500 \mathrm{IN}+10 \mathrm{M}+10 \mathrm{GS}$ & 10.1 & 0.745 & 53.17 & 5.370 & 0.396 \\
\hline $\mathrm{R} 10$ & $500 \mathrm{IN}+10 \mathrm{M}+10 \mathrm{GS}$ & 10.7 & 0.789 & 55.35 & 5.923 & 0.437 \\
\hline R11 & $500 \mathrm{IN}+10 \mathrm{M}+10 \mathrm{GS}$ & 9.6 & 0.708 & 63.34 & 6.081 & 0.448 \\
\hline R12 & $500 \mathrm{IN}+10 \mathrm{M}+10 \mathrm{GS}$ & 11.5 & 0.848 & 53.23 & 6.122 & 0.451 \\
\hline \multicolumn{2}{|c|}{$\begin{array}{c}\text { Average R9-R12 } \\
\pm \text { st.dev. }\end{array}$} & $\begin{array}{c}10.48 \\
\pm 0.82 \\
\end{array}$ & $\begin{array}{c}0.772 \\
\pm 0.060\end{array}$ & $\begin{array}{c}56.27 \\
\pm 4.82 \\
\end{array}$ & $\begin{array}{c}\mathbf{5 . 8 7 4} \\
\pm \mathbf{0 . 3 4 7} \\
\end{array}$ & $\begin{array}{c}0.433 \\
\pm 0.025 \\
\end{array}$ \\
\hline R13 & $500 \mathrm{IN}+10 \mathrm{M}+10 \mathrm{BL}$ & 9.9 & 0.737 & 48.55 & 4.806 & 0.358 \\
\hline R14 & $500 \mathrm{IN}+10 \mathrm{M}+10 \mathrm{BL}$ & 9.7 & 0.722 & 48.56 & 4.711 & 0.351 \\
\hline $\mathrm{R} 15$ & $500 \mathrm{IN}+10 \mathrm{M}+10 \mathrm{BL}$ & 10.1 & 0.752 & 52.82 & 5.335 & 0.397 \\
\hline \multicolumn{2}{|c|}{ Average R13-R15 } & 9.90 & 0.737 & 49.97 & 4.950 & 0.369 \\
\hline \pm st.dev. & & \pm 0.20 & \pm 0.015 & \pm 2.46 & \pm 0.336 & \pm 0.025 \\
\hline
\end{tabular}

Note: $l \cdot g_{\text {DoM }}^{-1}$ litres per $1 \mathrm{~g}$ dry organic matter added (added fresh biomass into inoculums).

Mostly, the methane yield produced from molasses is higher than obtained from grain sweeps. The use of birch leaves in co-fermentation with molasses yielded in a lower average methane yield $0.3691 \cdot \mathrm{g}^{-1}$ DOM, but it is very good compared to many other raw materials.

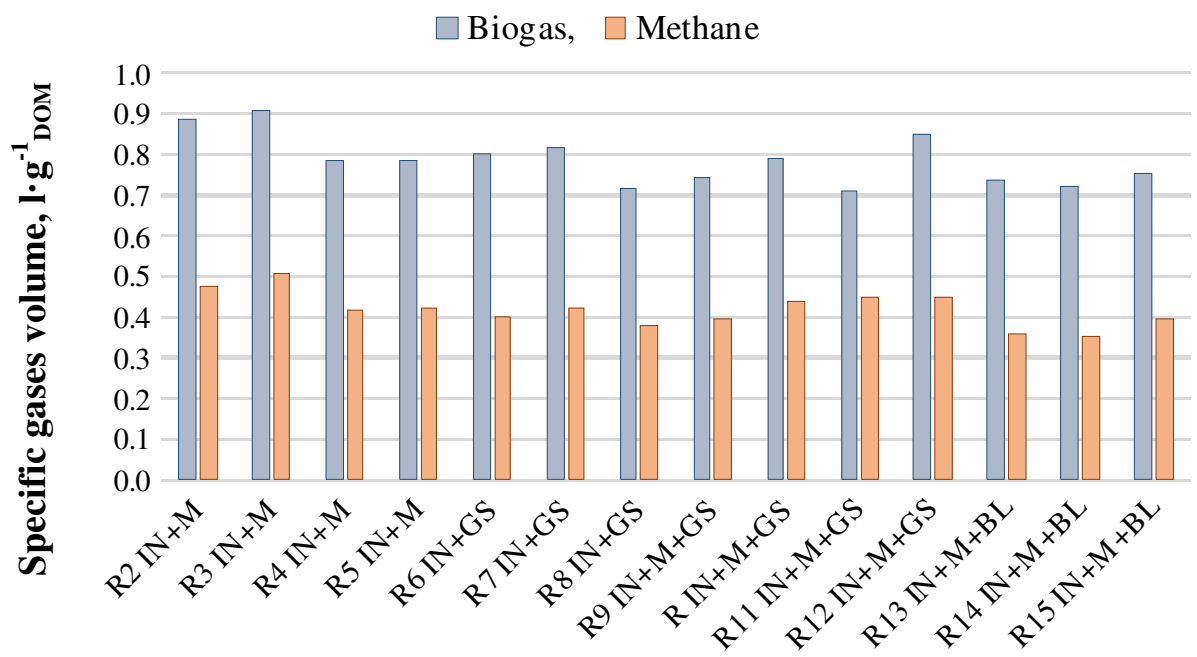

Bioreactor

Fig. 1. Specific biogas and methane yields

The average methane contents in biogas from molasses, birch leaves and grain residue sweep samples are shown in Fig. 2.

The highest average methane content was obtained from the bioreactors, where molasses and grain sweeps were co-fermented. This could be explained by the fact that molasses and grain residues form the substrate environment that is favourable for anaerobic bacteria activity. 


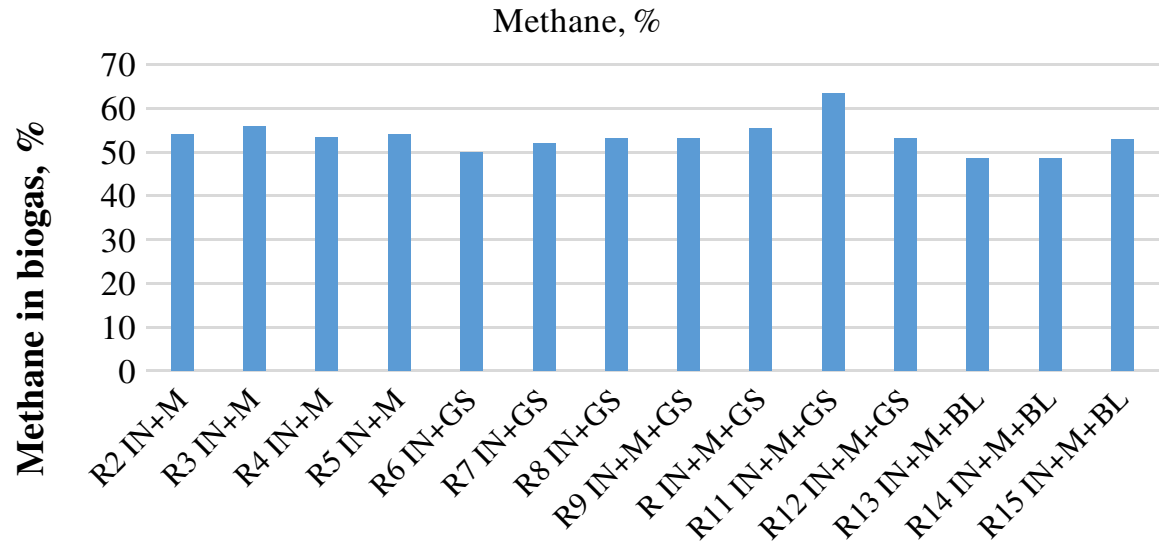

Bioreactor

Fig. 2. Average methane contents in biogas from molasses, birch leaves and grain residues (sweeps)

\section{Conclusions}

1. Molasses is a better raw material, providing by $13.68 \%$ higher methane yield compared to grains sweeps.

2. Molasses co-fermentation with grain sweeps in ratio of 1:1 improves the yield of methane by $7.71 \%$.

3. Molasses co-fermentation with fallen birch leaves in ratio of 1:1 gives by $17.34 \%$ lower average methane yield than that obtained from molasses and grain sweeps at the same proportion of the mixture.

4. Fallen birch leaves can be used as the raw material for methane production in bioreactors.

\section{References}

[1] Quintana N., Kooy F, Rhee M.D., Gerben P. V, Verpoorte R. Renewable energy from Cyanobacteria: energy production optimization by metabolic pathway engineering. Appl. Microbiol Biotechnol., 2011, 91(3), pp. 471-490.

[2] Dubrovskis V., Plume I. Biogas production from sugar rich waste. Agronomy Research, Volume 14, Issue 1, 2016, pp. 25-32.

[3] Dubrovskis V.,Plume, I., Straume I. Anaerobic co-fermentation of molasses and oil with straw pellets. Agronomy Research, vol. 16, number 3, 2018, pp. 688-695.

[4] Park M.J., Jo J.H., Park D., Lee D.S., Park J.M.Comprehensive study on a two-stage anaerobic digestion process for the sequential production of hydrogen and methane from cost-effective molasses.International Journal of Hydrogen Energy,35(12), 2010, pp. 6194-6202.

[5] Sarker S.,MøllerH.B. Boosting biogas yield of anaerobic digesters by utilizing concentrated molasses from 2nd generation bioethanol plant.International Journal of Energy, Environment and Economics 4, 2013, pp. 1-13.

[6] Sarker S.,H.B.Regulating feeding and increasing methane yield from co-digestion of C5 molasses and cattle manure.Energy Conversion and Management,2014, 84,pp. 7-12.

[7] Kitaoka S.,Sakata T., UtsugiH. Methane Emission from Leaves of Larch, Birch and Oak Saplings Grown at Elevated CO2 Concentration in Northern Japan-Preliminary Study. Journal of Agricultural Meteorology,2007, 63(4), pp. 201-206.

[8] Sundqvist E.P.,CrillP., Mölder M., Vestin P., LindrothA. Atmospheric methane removal by boreal plants. Geophys. Res. Lett.,2012, 39, L21806.

[9] Thran D. Methodenhandbuch Energetische Biomassenutzung, (Methods Manual Energetic use ofbiomass). 2010, Leipzig, 93 p. (In German).

[10] VDI 4630. Vergärungorganischer Stoffe Substratcharakterisierung, Probenahme, Stoffdatenerhebung, Gärversuche. Vereindeutscher Ingenieure (Fermentation of organic substances Substrate characterization,sampling, substance data collection, fermentation tests. German engineers), 2006, Düsseldorf, 48 p. (in German). 